\title{
Aromatic-based hydrocarbon pool mechanism for methanol-to-olefins conversion in H-SAPO-18: A van der Waals density functional study
}

\author{
Chuan-Ming Wang*, Yang-Dong Wang, Hong-Xing Liu, Guang Yang, Yu-Jue Du, Zai-Ku Xie\# \\ SINOPEC Shanghai Research Institute of Petrochemical Technology, Shanghai 201208, China
}

\section{A R T I C L E I N F O}

Article history:

Received 14 March 2015

Accepted 13 May 2015

Published 20 September 2015

\section{Keywords:}

Methanol-to-olefins conversion

Zeolite catalysis

Density functional theory

H-SAPO-18 zeotype

Reaction mechanism

Aromatic-based cycle

\begin{abstract}
A B S T R A C T
The reaction mechanism of zeolite-catalyzed methanol-to-olefins (MTO) conversion is still debated Aromatics and/or olefins themselves may act as hydrocarbon pool species in the reaction. In this work we used periodic density functional theory calculations with the van der Waals density functional to study the aromatic-based hydrocarbon pool mechanism in H-SAPO-18 zeotype with eight-membered ring openings. The distribution of different polymethylbenzenes (MBs) in H-SAPO-18 was evaluated from adsorption and interconversion analysis. Hexamethylbenzene was calculated to be the primary component of MBs in H-SAPO-18. Gibbs free energy analysis on the process of ethyl side chain propagation indicated that hexamethylbenzene was not more reactive than pentamethylbenzene and tetramethylbenzene. The overall Gibbs free energy barriers were calculated to be more than $200 \mathrm{~kJ} / \mathrm{mol}$ at MTO reaction temperature $(673 \mathrm{~K})$. These calculated results would provide some implications for understanding the reaction mechanism and the role of aromatics in MTO conversion.
\end{abstract}

(C) 2015, Dalian Institute of Chemical Physics, Chinese Academy of Sciences. Published by Elsevier B.V. All rights reserved.

\section{Introduction}

Zeolite-catalyzed methanol-to-olefins (MTO) conversion has attracted much interest from academic and industrial communities because it provides an alternative route to produce ethene and propene from non-crude oil resources, such as coal, natural gas and biomass [1,2]. Silicoaluminophosphate-34 zeotype (H-SAPO-34) has proven to be one of the most promising catalysts for MTO conversion because the total selectivity to ethene and propene is greater than $80 \%[3,4]$. To increase selectivity towards desired products and tailor the selectivity ratio of propene to ethene, it is essential to rationally design catalysts from knowledge of the reaction mechanism.

It is very challenging to understand the reaction mechanism of MTO conversion, and which has been still disputed since the discovery of MTO conversion three decades ago [5-8]. This is because the distribution of products and reaction intermediates in MTO conversion are complex. The current consensus is that MTO conversion proceeds through an indirect hydrocarbon pool mechanism [9], and both inorganic zeolites and organic hydrocarbon pool species act as co-catalytic active components. Methanol reacts with hydrocarbon pool species to build alkyl chains and the latter split off to produce light olefins. Polymethylbenzenes (MBs) and olefins were previously proposed to be hydrocarbon pool species for MTO conversion, which evolve into two different reaction cycles, aromatic-based and olefin-based cycles [10-16]. It is believed that the product distribution of MTO conversion highly depends on the relative

\footnotetext{
* Corresponding author. Tel: +86-21-68462197; Fax: +86-21-68462283; E-mail: wangcm.sshy@sinopec.com

\# Corresponding author. Tel: +86-21-68462197; Fax: +86-21-68462283; E-mail: xzk@sinopec.com

This work was supported by the National Natural Science Foundation of China $(21103231,91434102)$ and SINOPEC.

DOI: 10.1016/S1872-2067(15)60891-9 | http://www.sciencedirect.com/science/journal/18722067 | Chin. J. Catal., Vol. 36, No. 9, September 2015
} 

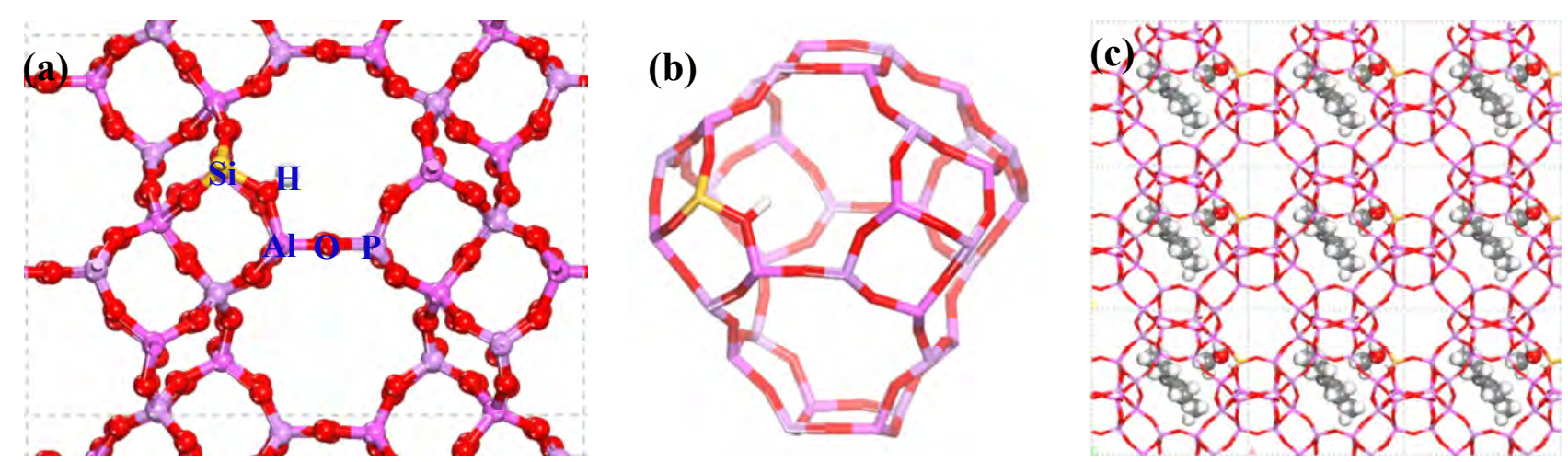

Fig. 1. Structure of H-SAPO-18 zeotype using periodic 48T model (a). The cavity is highlighted for clarity (b). There are no spurious interactions between organic species in periodically repeated unit cells (c).

contribution of each cycle, which is related to catalyst structures and reaction conditions [17,18]. In H-ZSM-5 catalyzed MTO conversion, Svelle et al. [12] proposed that ethene was exclusively produced from the aromatic-based cycle, while propene and higher olefins were produced from the olefin-based cycle. It has been proposed that aromatic-based cycle may evolve from side chain or paring routes [19-26]. Our previous theoretical kinetic calculations indicated that the paring route plays a minor role in MTO conversion [26].

Besides H-SAPO-34 and H-ZSM-5, many other zeolites or zeotypes have been systematically explored to understand structure-performance relationship and reaction mechanism of MTO conversion [27,28]. H-SAPO-18, a three-dimensional interconnected zeotype with the same size of pore openings as H-SAPO-34 (0.38 nm $\times 0.38 \mathrm{~nm})$, exhibits good activity and selectivity for MTO conversion [29-35]. The primary products using H-SAPO-18 were also propene and ethene. H-SAPO-18 can also intergrow with H-SAPO-34 during catalyst preparation [32]. To gain a better understanding of the MTO reaction mechanism and the effect of framework topology, we theoretically studied the aromatic-based hydrocarbon pool mechanism in H-SAPO-18 using the static density functional theory (DFT) method. The ab initio molecular dynamics (AIMD) method has recently been employed to study the adsorption of hydrocarbons and simple chemical reactions in zeolites, taking the temperature and surroundings explicitly into account [36,37]. Although larger spaces can be sampled on potential energy surfaces, it is currently still challenging to deal with reactions in- volving complex networks using the advanced AIMD method.

\section{Computational details}

All DFT calculations applying periodic boundary conditions were carried out using the Vienna Ab initio Simulation Package (VASP 5.3.5) [38]. Electron-ion interactions were described using the projector augmented wave (PAW) method $[39,40]$. The Bayesian error estimation functional with van der Waals (vdW) correlation (BEEF-vdW) was used [41]. The plane wave basis set kinetic energy cutoff was $400 \mathrm{eV}$. Sampling of the Brillouin zone only used the $\Gamma$ point. The dimer method was used to locate transition states [42]. A force threshold of 0.1 $\mathrm{eV} / \mathrm{nm}$ was used for the optimization of all structures. The harmonic frequency calculations employed a partial Hessian vibrational analysis (PHVA), including the $\mathrm{H}$ atom of acidic site and organic species of involved states [43]. The zero point energies (ZPE), enthalpies, entropies and Gibbs free energies were then calculated from harmonic frequencies.

The H-SAPO-18 zeotype exhibiting an AEI framework topology was modeled by a periodic 48T cell [44]. The Brønsted acid site was located between T2 and T1 sites in H-SAPO-18 because it was the most stable site (see Fig. 1) [45]. The lattice constants were optimized using an $800 \mathrm{eV}$ energy cutoff and $0.1 \mathrm{eV} / \mathrm{nm}$ force threshold $(1.391,1.287,1.879 \mathrm{~nm}$ for AlP0-18), which was similar to the experimental lattice constants $(1.371,1.273,1.857 \mathrm{~nm})$ [44]. The positions of all atoms were allowed to relax in the calculations while the lattice con-

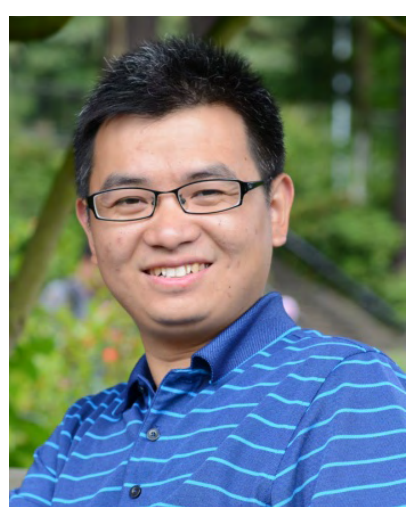

Chuan-Ming Wang (SINOPEC Shanghai Research Institute of Petrochemical Technology) received the Catalysis Rising Star Award in 2012, which was presented by The Catalysis Society of China. He received his Ph.D. degree in Physical Chemistry from Fudan University in 2008 under the supervision of Professor Zhi-Pan Liu with the thesis on oxide supported gold catalysis. He stayed one year as visiting scholar at SUNCAT Center for Interface Science and Catalysis of Professor Jens K. Norskov in Stanford University and SLAC National Accelerator Laboratory, applying the descriptor-based catalyst design approach in zeolite catalysis. His research interests cover reaction mechanism, structure-performance relationship and rational design of catalysts in heterogeneous catalysis, in particular in zeolite catalysis, using state of the art first-principle methods. 


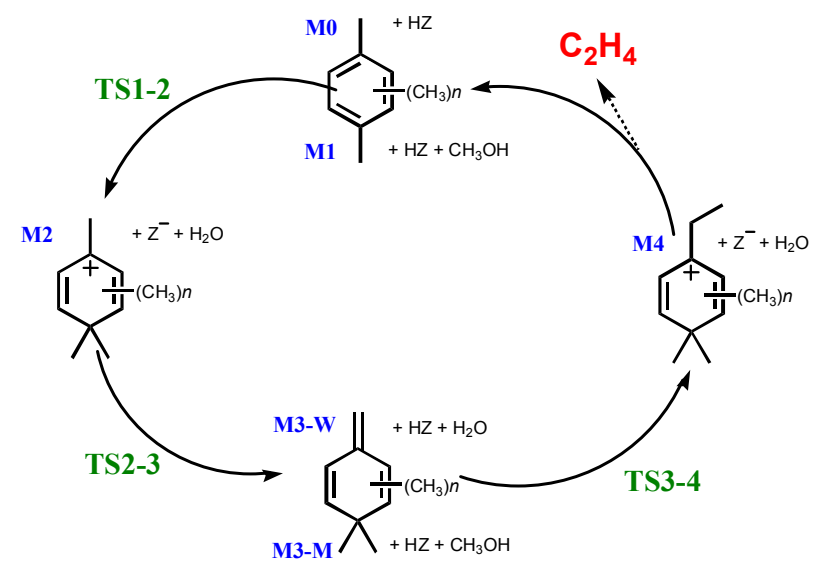

Scheme 1. Abbreviated MB-based hydrocarbon pool mechanism in zeolites (HZ) for MTO conversion.

stants were fixed at the optimized values.

\section{Results and discussion}

A simplified picture of the aromatic-based cycle following a side chain hydrocarbon pool mechanism to produce ethene is shown in Scheme 1. The complete cycle consists of alkyl side chain propagation and elimination, as extensively addressed in previous theoretical work [20-25]. The gem-methylation (TS1-2) of aromatics like MBs leads to the formation of polymethylbenzenium ions (polyMB+, M2). These ions then undergo deprotonation to form polymethylmethylenecyclohexadiene (PMMC) intermediates with an exocyclic double bond (M3). The ethyl side chain grows through the methylation of the exocyclic double bond (TS3-4). The elimination of the ethyl side chain produces ethene as a product and closes one catalytic cycle. As shown previously, the subsequent deprotonation of M4 and methylation of the corresponding PMMC leads to the propagation of higher alkyl chains [24]. A more facile process involving simultaneous $\mathrm{C}$-C bond breaking and deprotonation of the terminal methyl group of the side chain was proposed to eliminate ethyl or iso-propyl side chains [23].

For reactions involving complex networks, it is challenging to rationalize the calculated kinetics. The energetic span model was proposed by Shaik et al. [46] to conceptualize catalytic cycles. They demonstrated that there were no rate-determining steps, but rate-determining states in catalytic cycles. Based on this concept, we confirmed in H-SAPO-34 that the methylation for ethyl side chain growth (TS3-4) was the rate-determining transition state and that ethene was selectively favored over propene in the aromatic-based cycle $[24,47]$. In this work, two methylation steps (TS1-2, TS3-4) and some relevant important intermediates (M0, M1, M2, and M3-M) were studied. The deprotonation step of poly $\mathrm{MB}^{+}$ions to PMMC intermediates (TS2-3) is usually endothermic and was not included in the study.

\subsection{Adsorption and interconversion of MBs in H-SAPO-18}

Understanding the static adsorption energy and interconversion thermodynamics of aromatics such as MBs in zeolite cavities is important for estimating the distribution of MBs as hydrocarbon pool species or coking precursors. For these kinds of non-bonding host-guest interactions, vdW interactions are very important and need to be taken into account explicitly. Table 1 summarizes the calculated adsorption energies and enthalpies of 11 MBs in H-SAPO-18 and AlPO-18. The adsorp-

Table 1

Structures, adsorption energies $\left(E_{\text {ads }}(\mathrm{MB})\right.$, without ZPE correction), and adsorption enthalpies $\left(H_{\mathrm{ads}}(\mathrm{MB})\right.$, with ZPE correction) of investigated MBs in H-SAPO-18 and AlPO-18. All values are in $\mathrm{kJ} / \mathrm{mol}$.

\begin{tabular}{|c|c|c|c|c|c|c|c|c|c|}
\hline MB & Structure & $\begin{array}{l}H_{\text {ads }}(\mathrm{MB}) \text { in } \\
\text { H-SAPO-18 }\end{array}$ & $\begin{array}{l}E_{\text {ads }}(M B) \text { in } \\
\text { H-SAPO-18 }\end{array}$ & $\begin{array}{c}E_{\text {ads }}(\mathrm{MB}) \text { in } \\
\text { AlPO-18 }\end{array}$ & MB & Structure & $\begin{array}{l}H_{\text {ads }}(\mathrm{MB}) \text { in } \\
\text { H-SAPO-18 }\end{array}$ & $\begin{array}{l}E_{\text {ads }}(M B) \text { in } \\
\text { H-SAPO-18 }\end{array}$ & $\begin{array}{c}E_{\text {ads }}(M B) \text { in } \\
\text { AlPO-18 }\end{array}$ \\
\hline Benzene & & -67 & -67 & -63 & 1,2,4-TriMB & & -96 & -99 & -97 \\
\hline Toluene & & -83 & -84 & -82 & 1,2,3,5-TMB & & -85 & -90 & -89 \\
\hline$o$-xylene & & -93 & -93 & -93 & $1,2,4,5$-ТMВ & & -106 & -110 & -108 \\
\hline$m$-xylene & & -91 & -92 & -88 & PMB & & -92 & -98 & -95 \\
\hline$p$-xylene & & -90 & -91 & -88 & HMB & & -69 & -77 & -74 \\
\hline 1,3,5-TriMB & & -93 & -96 & -93 & & & & & \\
\hline
\end{tabular}




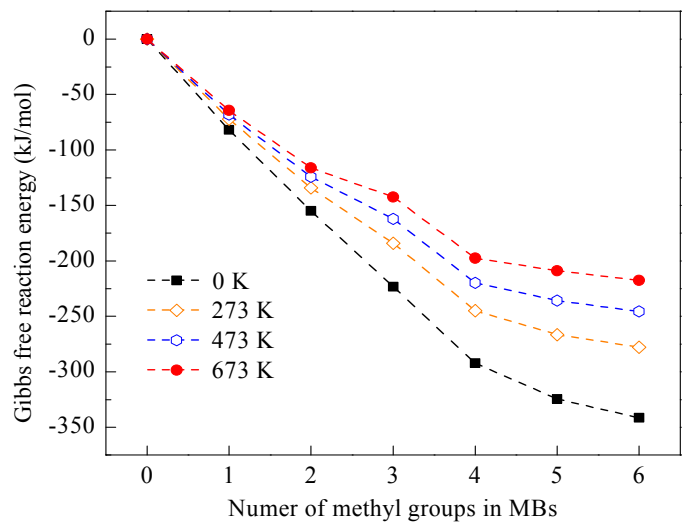

Fig. 2. Gibbs free reaction energies of MBs with different number of methyl groups from benzene via repeated methanol methylation in H-SAPO-18. All energies are relative to gaseous methanol and water.

tion of a hydrocarbon in zeolites usually depends on two opposite effects, stabilization from vdW interactions and destabilization from steric repulsion interactions with the frameworks.

Generally the adsorption of MBs in AlPO-18 was slightly weaker than those in H-SAPO-18 $(<4 \mathrm{~kJ} / \mathrm{mol})$, indicating that the adsorption energy of MBs was dominated by non-localized vdW and steric interactions. The adsorption enthalpies of benzene and toluene in H-SAPO-18 were calculated to be -67 and $-83 \mathrm{~kJ} / \mathrm{mol}$, respectively. There was almost no difference in adsorption enthalpies of three xylenes ( -90 to $-93 \mathrm{~kJ} / \mathrm{mol}$ ). Steric confinement effects began to appear on the adsorption of tetramethylbenzene (TMB). The adsorption enthalpy of $1,2,3,5-\mathrm{TMB}$ was lower than that of $1,2,4,5-\mathrm{TMB}$ (-85 vs. -106 $\mathrm{kJ} / \mathrm{mol}$ ). From toluene to $1,2,4,5-\mathrm{TMB}$, the adsorption enthalpy increased in H-SAPO-18 with the addition of methyl groups because of vdW interactions. However, the adsorption enthalpies of pentamethylbenzene (PMB) and hexamethylbenzene (HMB) were -92 and $-69 \mathrm{~kJ} / \mathrm{mol}$, respectively, which were lower than that of $1,2,4,5$-TMB. This indicated that the H-SAPO-18 framework was not spacious enough to accommodate higher MBs (PMB and HMB) as restricted free hydrocarbon pool species.

The interconversion of MBs with different numbers of methyl groups usually proceeds through a methylation reaction with methanol or methoxide in zeolites during MTO conversion. We calculated Gibbs free reaction energies at different temperatures for the transformation of benzene to different MBs to understand the interconversion thermodynamics of MBs in H-SAPO-18 (see Fig. 2). For MBs with same number of methyl groups we considered the structure with the highest adsorption energy. Methanol and water in the gaseous phase were included for energy reference. The primary component of MBs entrapped in zeolites was the one exhibiting the highest exothermicity.

As shown in Fig. 2, the Gibbs free reaction energy from benzene to toluene was $-82 \mathrm{~kJ} / \mathrm{mol}$ at $0 \mathrm{~K}$, and which decreased by approximately $-70 \mathrm{~kJ} / \mathrm{mol}$ by adding one additional methyl group from toluene to 1,2,4,5-TMB. The interconversions from 1,2,4,5-TMB to PMB and from PMB to HMB were also exother- mic by -32 and $-17 \mathrm{~kJ} / \mathrm{mol}$, respectively at $0 \mathrm{~K}$, although steric repulsion interactions were prominent for both MBs. The Gibbs reaction free energies from benzene to higher MBs increased monotonously in absolute value in H-SAPO-18, which peaked at $340 \mathrm{~kJ} / \mathrm{mol}$ for $\mathrm{HMB}$ at $0 \mathrm{~K}$. With increasing temperature, we found that the Gibbs free reaction energies decreased in absolute value and the reaction free energies towards higher MBs were more sensitive to temperature than those of lower MBs. This indicated that the reaction temperature influenced the distribution of MBs. At the MTO reaction temperature (673 K), the Gibbs reaction free energies to PMB and HMB were still approximately $-10 \mathrm{~kJ} / \mathrm{mol}$ for adding one methyl group.

Analysis of the distribution of MBs in zeolites using static adsorption energies or interconversion thermodynamics is not always consistent. In H-SAPO-18, it was 1,2,4,5-TMB that adsorbed the strongest, while HMB had the highest exothermicity during the interconversion. This is understandable because the vdW interactions for stabilization still outweighed the steric confinement effects for destabilization in the adsorption of PMB and HMB in H-SAPO-18. The interconversion thermodynamics analysis offers a more accurate possibility for assessing the distribution of MBs in zeolites.

\subsection{Aromatic-based cycle in $\mathrm{H}-\mathrm{SAPO}-18$}

Fig. 3 presents the calculated enthalpy, entropy and Gibbs free energy diagrams of MB-based cycles in H-SAPO-18 for the propagation of ethyl side chain at $673 \mathrm{~K}$. The calculated adsorption enthalpies of methanol in H-SAPO-18 were approximately -91 to $-95 \mathrm{~kJ} / \mathrm{mol}$ in the presence of MBs, which was similar to those in H-SAPO-34 ( -83 to $-92 \mathrm{~kJ} / \mathrm{mol}$ ) [24]. The enthalpy barriers for gem-methylation in H-SAPO-18 were 119, 130, 123 and $130 \mathrm{~kJ} / \mathrm{mol}$ for 1,2,3,5-TMB, 1,2,4,5-TMB, PMB and $\mathrm{HMB}$, respectively. It should be mentioned that the energy barriers without ZPE correction in H-SAPO-34 were 115 and $105 \mathrm{~kJ} / \mathrm{mol}$ for 1,2,3,5-TMB and HMB, respectively [24]. The enthalpy barriers of PMMC methylation in 1,2,3,5-TMB-, 1,2,4,5-TMB-, PMB- and HMB-based cycles were 104, 112, 99 and $126 \mathrm{~kJ} / \mathrm{mol}$, respectively. Both methylation steps (TS1-2, and TS3-4) in the HMB-based cycle needed to overcome higher enthalpy barriers than in the PMB- and TMB-based cycles. The transition state structures for both methylation steps in H-SAPO-18 are shown in Fig. 4. In the transition states of the gem-methylation step, the distances of the breaking $\mathrm{O}-\mathrm{H}$ bond and forming $\mathrm{C}-\mathrm{C}$ bond were approximately $0.22 \mathrm{~nm}$. During the methylation step of PMMC, the distances of the breaking $\mathrm{O}-\mathrm{H}$ bond and forming $\mathrm{C}-\mathrm{C}$ bond were approximately 0.20 and 0.23 $\mathrm{nm}$, respectively. Because the methylation of intermediates with exocyclic double bonds is rate-determining, the overall enthalpy barriers (M1 $\rightarrow$ TS3-4) were 171, 177, 165 and 181 kJ/mol for 1,2,3,5-TMB-, 1,2,4,5-TMB-, PMB- and HMB-based cycles, respectively. These barriers were larger than the overall energy barriers in H-SAPO-34 ( $150 \mathrm{~kJ} / \mathrm{mol}$ for 1,2,3,5-TMBand HMB-based cycles, respectively) [24].

The overall Gibbs free energy barriers at $673 \mathrm{~K} \mathrm{(M0} \rightarrow$ TS3-4) were 224, 208, 215 and $239 \mathrm{~kJ} / \mathrm{mol}$ in 1,2,3,5-TMB-, 1,2,4,5-TMB-, PMB- and HMB-based cycles, respectively, with 

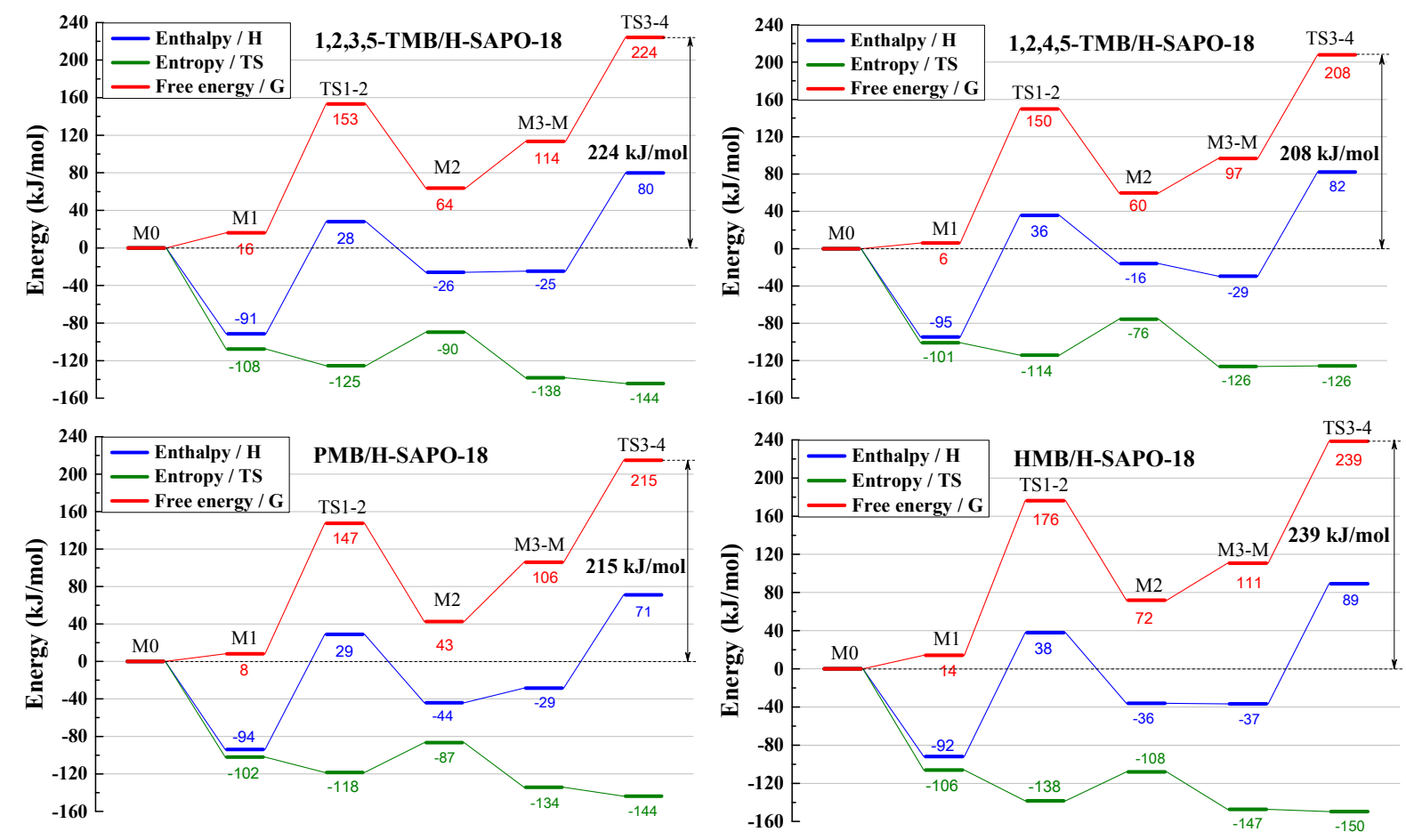

Fig. 3. Schematic enthalpy, entropy, and Gibbs free energy diagrams of abbreviated MB-based cycle in H-SAPO-18 at $673 \mathrm{~K}$.

the inclusion of entropy effects. The stronger steric constraint of the H-SAPO-18 framework on the transition state (TS3-4) in HMB-, PMB- and 1,2,3,5-TMB-based cycles resulted in relatively higher entropy loss (144-150 kJ/mol) compared with that for the 1,2,4,5-TMB-based cycle $(126 \mathrm{~kJ} / \mathrm{mol})$. From these results it is evident that HMB is not more reactive than $\mathrm{PMB}$ and TMB because of the confinement effect of the H-SAPO-18 framework on $\mathrm{HMB}$ and reaction intermediates, which is similar to our previous work in H-SAPO-34 [22,24]. Furthermore, because HMB was the primary MBs component in H-SAPO-18, the MTO conversion needed to overcome a higher Gibbs free energy barrier if the reaction only followed the aromatic-based cycle in H-SAPO-18. In H-SAPO-34, we theoretically demonstrated that olefins other than MBs were the dominating hydrocarbon pool species for MTO conversion [15,47]. Because the overall energy barriers of the aromatic-based cycle in H-SAPO-18 were even higher than those in H-SAPO-34, we believe that the olefin-based cycle in H-SAPO-18 cannot be ignored. A comprehensive investigation on the olefin-based cycle in H-SAPO-18 is underway.

\section{Conclusions}

Using periodic DFT calculations with a vdW interactions corrected XC functional, we systematically investigated the aromatic-based cycle for MTO conversion in H-SAPO-18. We found that $\mathrm{HMB}$ was the primary MBs component in H-SAPO-18 from static adsorption and dynamic interconversion analysis. However, it was 1,2,4,5-TMB that adsorbed the strongest in H-SAPO-18. The overall Gibbs free energy barriers

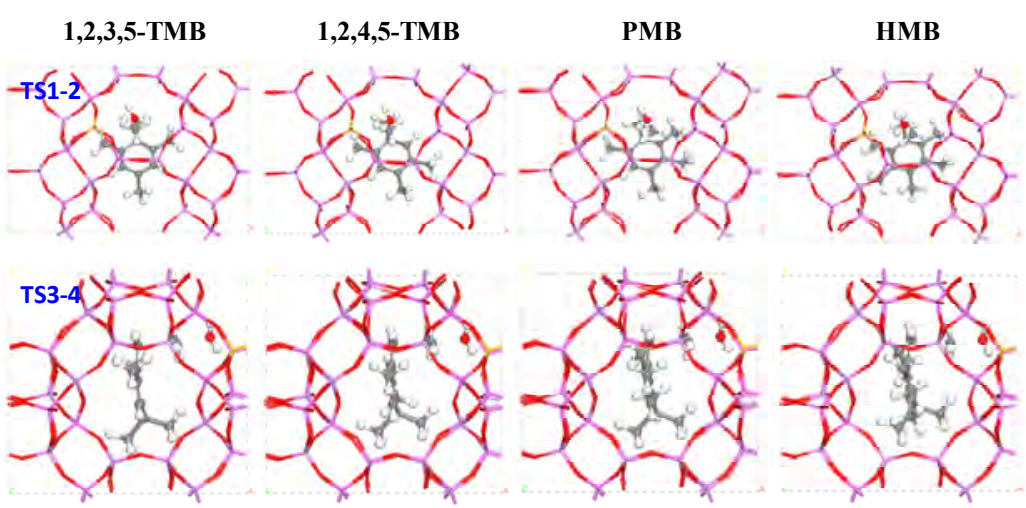

Fig. 4. Transition state structures for the gem-methylation (TS1-2) and methylation of PMMC (TS3-4) in MB-based cycle in H-SAPO-18. The imaginary frequencies relating to the reaction coordinates in TS1-2 and TS3-4 are around -380 and $-440 \mathrm{~cm}^{-1}$, respectively. 


\section{Graphical Abstract}

Chin. J. Catal., 2015, 36: 1573-1579 doi: 10.1016/S1872-2067(15)60891-9

\section{Aromatic-based hydrocarbon pool mechanism for methanol-to-olefins conversion in H-SAPO-18: A van der Waals density functional study}

Chuan-Ming Wang*, Yang-Dong Wang, Hong-Xing Liu, Guang Yang, Yu-Jue Du, Zai-Ku Xie*

SINOPEC Shanghai Research Institute of Petrochemical Technology

Hexamethylbenzene was theoretically proven to be the primary component of methylbenzenes in H-SAPO-18. The overall Gibbs free energy barriers of the aromatic-based cycle were greater than $200 \mathrm{~kJ} / \mathrm{mol}$ at $673 \mathrm{~K}$ in H-SAPO-18.

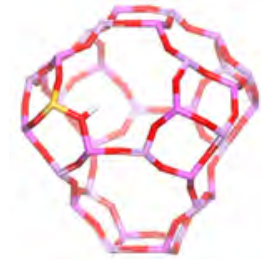

H-SAPO-18

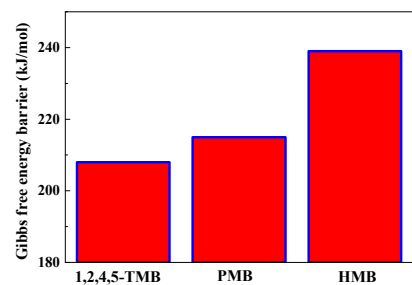

for 1,2,4,5-TMB-, PMB- and HMB-based cycles in H-SAPO-18 were calculated to be 208, 215 and $239 \mathrm{~kJ} / \mathrm{mol}$, respectively. HMB was not more reactive than PMB and TMB. The confinement effect of the zeolite framework was prominent in the aromatic-based cycle, in particular when bulky aromatics acted as hydrocarbon pool species. The kinetics of the aromatic-based cycle would help to address the MTO reaction mechanism when compared to the kinetics of the olefin-based cycle.

\section{References}

[1] Chang C D, Silvestri A J. J Catal, 1977, 47: 249

[2] Chang C D. Catal Rev Sci Eng, 1983, 25: 1

[3] Stocker M. Microporous Mesoporous Mater, 1999, 29: 3

[4] Tian P, Wei Y X, Ye M, Liu Z M. ACS Catal, 2015, 5: 1922

[5] Olsbye U, Svelle S, Bjørgen M, Beato P, Janssens T V W, Joensen F, Bordiga S, Lillerud K P. Angew Chem Int Ed, 2012, 51: 5810

[6] Hemelsoet K, Van der Mynsbrugge J, De Wispelaere K, Waroquier M, Van Speybroeck V. ChemPhysChem, 2013, 14: 1526

[7] Olsbye U, Bjørgen M, Svelle S, Lillerud K P, Kolboe S. Catal Today, 2005, 106: 108

[8] Haw J F, Song W G, Marcus D M, Nicholas J B. Acc Chem Res, 2003, 36: 317

[9] Dahl I M, Kolboe S. J Catal, 1996, 161: 304

[10] Arstad B, Kolboe S. J Am Chem Soc, 2001, 123: 8137

[11] Song W G, Haw J F, Nicholas J B, Heneghan C S. J Am Chem Soc, 2000, 122: 10726

[12] Svelle S, Joensen F, Nerlov J, Olsbye U, Lillerud K P, Kolboe S, Bjørgen M.J Am Chem Soc, 2006, 128: 14770

[13] Bjørgen M, Svelle S, Joensen F, Nerlov J, Kolboe S, Bonino F, Palumbo L, Bordiga S, Olsbye U. J Catal, 2007, 249: 195

[14] Svelle S, Olsbye U, Joensen F, Bjørgen M. J Phys Chem C, 2007, 111 17981

[15] Wang C M, Wang Y D, Xie Z K. J Catal, 2013, 301: 8

[16] Dai W L, Wang C M, Dyballa M, Wu G J, Guan N J, Li L D, Xie Z K, Hunger M. ACS Catal, 2015, 5: 317

[17] Hereijgers B P C, Bleken F, Nilsen M H, Svelle S, Lillerud K P, Bjørgen M, Weckhuysen B M, Olsbye U. J Catal, 2009, 264: 77

[18] Wang C M, Li B W, Wang Y D, Xie Z K. J Energy Chem, 2013, 22: 914

[19] Van Speybroeck V, De Wispelaere K, Van der Mynsbrugge J, Vandichel M, Hemelsoet K, Waroquier M. Chem Soc Rev, 2014, 43:
7326

[20] Wang C M, Wang Y D, Xie Z K, Liu Z P. J Phys Chem C, 2009, 113 4584

[21] Lesthaeghe D, Horre A, Waroquier M, Marin G B, Van Speybroeck V. Chem Eur J, 2009, 15: 10803

[22] Wang C M, Wang Y D, Liu H X, Xie Z K, Liu Z P. J Catal, 2010, 271: 386

[23] De Wispelaere K, Hemelsoet K, Waroquier M, Van Speybroeck V. J Catal, 2013, 305: 76

[24] Wang C M, Wang Y D, Xie Z K. Catal Sci Technol, 2014, 4: 2631

[25] Wang S, Wei Z H, Chen Y Y, Qin Z F, Ma H, Dong M, Fan W B, Wang J G. ACS Catal, 2015, 5: 1131

[26] Wang C M, Wang Y D, Liu H X, Xie Z K, Liu Z P. Microporous Mesoporous Mater, 2012, 158: 264

[27] Dai W L, Wang X, Wu G J, Guan N J, Hunger M, Li L D. ACS Catal, 2011, 1: 292

[28] Teketel S, Skistad W, Benard S, Olsbye U, Lillerud K P, Beato P, Svelle S. ACS Catal, 2012, 2: 26

[29] Chen J S, Thomas J M, Wright P A, Townsend R P. Catal Lett, 1994, 28: 241

[30] Chen J S, Thomas J M. J Chem Soc, Chem Commun, 1994: 603

[31] Marcus D M, Song W G, Ng L L, Haw J F. Langmuir, 2002, 18: 8386

[32] Wragg D S, Akporiaye D, Fjellvag H. J Catal, 2011, 279: 397

[33] Chen J R, Li J Z, Yuan C Y, Xu S T, Wei Y X, Wang Q Y, Zhou Y, Wang J B, Zhang M Z, He Y L, Xu S L, Liu Z M. Catal Sci Technol, 2014, 4: 3268

[34] Chen J R, Li J Z, Wei Y X, Yuan C Y, Li B, Xu S T, Zhou Y, Wang J B, Zhang M Z, Liu Z M. Catal Commun, 2014, 46: 36

[35] Djieugoue M A, Prakash A M, Kevan L. J Phys Chem B, 2000, 104: 6452

[36] Moors S L C, De Wispelaere K, Van der Mynsbrugge J, Waroquier M, Van Speybroeck V. ACS Catal, 2013, 3: 2556

[37] Van der Mynsbrugge J, Moors S L C, De Wispelaere K, Van Speybroeck V. ChemCatChem, 2014, 6: 1906

[38] Kresse G, Furthmüller J. Phys Rev B, 1996, 54: 11169

[39] Kresse G, Joubert D. Phys Rev B, 1999, 59: 1758

[40] Blöchl P E. Phys Rev B, 1994, 50: 17953

[41] Wellendorff J, Lundgaard K T, Møgelhøj A, Petzold V, Landis D D, Nørskov J K, Bligaard T, Jacobsen K W. Phys Rev B, 2012, 85: 235149/1

[42] Henkelman G, Jonsson H. J Chem Phys, 1999, 111: 7010

[43] Brogaard R Y, Wang C M, Studt F. ACS Catal, 2014, 4: 4504

[44] Baerlocher C, McCusker L B, Olson D H. Atlas of Zeolite 
Framework Types. 6th Ed. Elsevier, 2007

[45] Wang C M, Brogaard R Y, Xie Z K, Studt F. Catal Sci Technol, 2015, 5: 2814
[46] Kozuch S, Shaik S. Acc Chem Res, 2010, 44: 101

[47] Wang C M, Wang Y D, Du Y J, Yang G, Xie Z K. Catal Sci Technol, 2015, DOI: $10.1039 /$ C5CY00483G

\title{
H-SAPO-18催化甲醇制烯烃反应的芳烃烃池机理: 基于范德华校正的密度泛函理论研究
}

\author{
王传明", 王仰东, 刘红星, 杨 光, 杜钰玨, 谢在库
} 中国石油化工股份有限公司上海石油化工研究院, 上海201208

摘要: 由于可以从非石油资源如煤、天然气、生物质等出发制备低碳烯烃, 分子笁催化甲醇制烯烃(MTO)反应在学术界和工业界 引起了广泛的研究兴趣. H-SAPO-34是目前表现优异性能的分子篮催化剂之一, 其双烯(乙烯 + 丙烯)的选择性在 $80 \%$ 以上, 已经 实现了工业化应用. 为了提升MTO反应的选择性, 以及调控乙烯丙烯的选择性之比, 非常有必要从反应机理出发来优化设计新的 催化剂. 然而, 由于MTO催化反应产物复杂多样, 对MTO反应机理的认识还存在很大的争议. 目前基本能够接受的是MTO催化 反应沿着烃池机理进行. 在此反应机理中, 无机分子篎和有机烃池活性中心形成共催化剂, 甲醇进攻有机活性中心生成烷基链, 此烷基链断裂得到烯烃产物. 目前提出的烃池活性中心主要包括多甲基苯和烯烃自身, 它们分别沿着各自的循环反应网络(芳烃 循环和烯烃循环)生成烯烃产物. 有文献指出在H-ZSM-5分子篮中芳烃循环主要生成乙烯, 而烯烃循环主要生成丙烯等产物. 因 此, 系统研究分子篮结构对两条循环网络相对贡献程度的影响规律, 从而阐述分子篎结构和MTO催化性能之间的关系具有重要 的意义.

H-SAPO-18是一类结构上与H-SAPO-34相类似的分子笁, 其笼由八元环孔道互联. 实验研究指出, 其也具有优异的MTO催化 性能. 在本工作中, 我们利用包含范德华相互作用校正的交换相关泛函(BEEF-vdW), 系统研究了 H-SAPO-18分子篎中的芳烃循环 反应机理. 所有计算用VASP程序包完成, H-SAPO-18用48T周期性结构模型表示. 利用静态吸附和相互转化的自由能变化情况, 我们首先确认了反应条件下H-SAPO-18中最稳定的多甲基苯的结构. 计算结果指出, 1,2,4,5-四甲基苯的吸附能最强, 而六甲基苯 是主要存在的多甲基苯组分. 多甲基苯在分子篮孔道内的稳定性主要由两个相反的作用共同影响: 范德华相互作用引起的吸引, 以及分子篎孔道结构引起的排斥. 在芳烃循环路线中, 乙基侧链的增长是反应的关键基元步. 吉布斯自由能分析指出芳烃循环路 线中, 在反应温度 $673 \mathrm{~K}$ 下 H-SAPO-18中的六甲基苯并不比五甲基苯, 四甲基苯的活性高, 这与H-SAPO-34分子筛中的结果相一致. H-SAPO-18中的四甲基苯、五甲基苯和六甲基苯的总吉布斯自由能垒分别是208, 215, $239 \mathrm{~kJ} / \mathrm{mol}$. 六甲基苯循环路线所表现出的 高反应能垒的一个原因, 是由于分子篮几何限域效应引起的熵增加所致. 通过与烯烃循环路线的动力学进行比较, 本文芳烃循环 路线动力学的工作可以为 $\mathrm{MTO}$ 催化反应机理的研究提供一些启示.

关键词: 甲醇制烯烃; 分子笁催化; 密度泛函理论; H-SAPO-18分子篎; 反应机理; 芳烃循环路线

收稿日期: 2015-03-14. 接受日期: 2015-05-13. 出版日期: 2015-09-20.

*通讯联系人. 电话: (021)68462197; 传真: (021)68462283; 电子信箱: wangcm.sshy@sinopec.com

\#通讯联系人. 电话: (021)68462197; 传真: (021)68462283; 电子信箱: xzk@sinopec.com

基金来源：国家自然科学基金(21103231,91434102); 中国石化.

本文的英文电子版由Elsevier出版社在ScienceDirect上出版(http://www.sciencedirect.com/science/journal/18722067). 